\title{
Meningitis in Neonates:
}

\section{Role and interpretation of Cerebrospinal fluid}

Dr Daniella Carter, Dr Dina Sava, Dr Riem Farah, Dr Catherine Tremlett, Dr Rahul Roy

\section{Background}

Meningitis is a rare but potentially devastating condition in the neonatal population.

Local guidance is to perform lumbar puncture (LP) on term ( $>37$ weeks) and preterm (<37 weeks) neonates for perinatal risk factors and/or clinical signs of sepsis.

LPs can be delayed due to the clinical condition of the neonate and antibiotics are started

empirically. The cerebrospinal fluid (CSF) white cell count (WCC) is often used to aid the diagnosis of meningitis.

Traumatic LPs are common and complicate the interpretation of CSF WCC.

Conventionally meningitis is considered when the ratio of white cells to red cells is 1:500.

We aim to determine the role and interpretation of CSF in evaluation of early and late onset sepsis/meningitis in term and preterm babies.

\section{Method}

Retrospective review of case notes of neonates who had LP performed as part of early $(\leq 72 \mathrm{~h})$ and late ( $>72 \mathrm{~h}$ ) onset sepsis between February 2017 and February 2018

\section{Exclusion criteria}

Ventriculoperitoneal shunt

Intraventicular haemorrhage

Positive viral CSF PCR

\section{Definitions}

Traumatic tap: Red cell count $>500$

Proven meningitis: Positive CSF cultures with organisms not regarded as contaminants

\section{Results \\ Cell counts were available in 227 of 239 LPs. $36 \%$ were traumatic.}

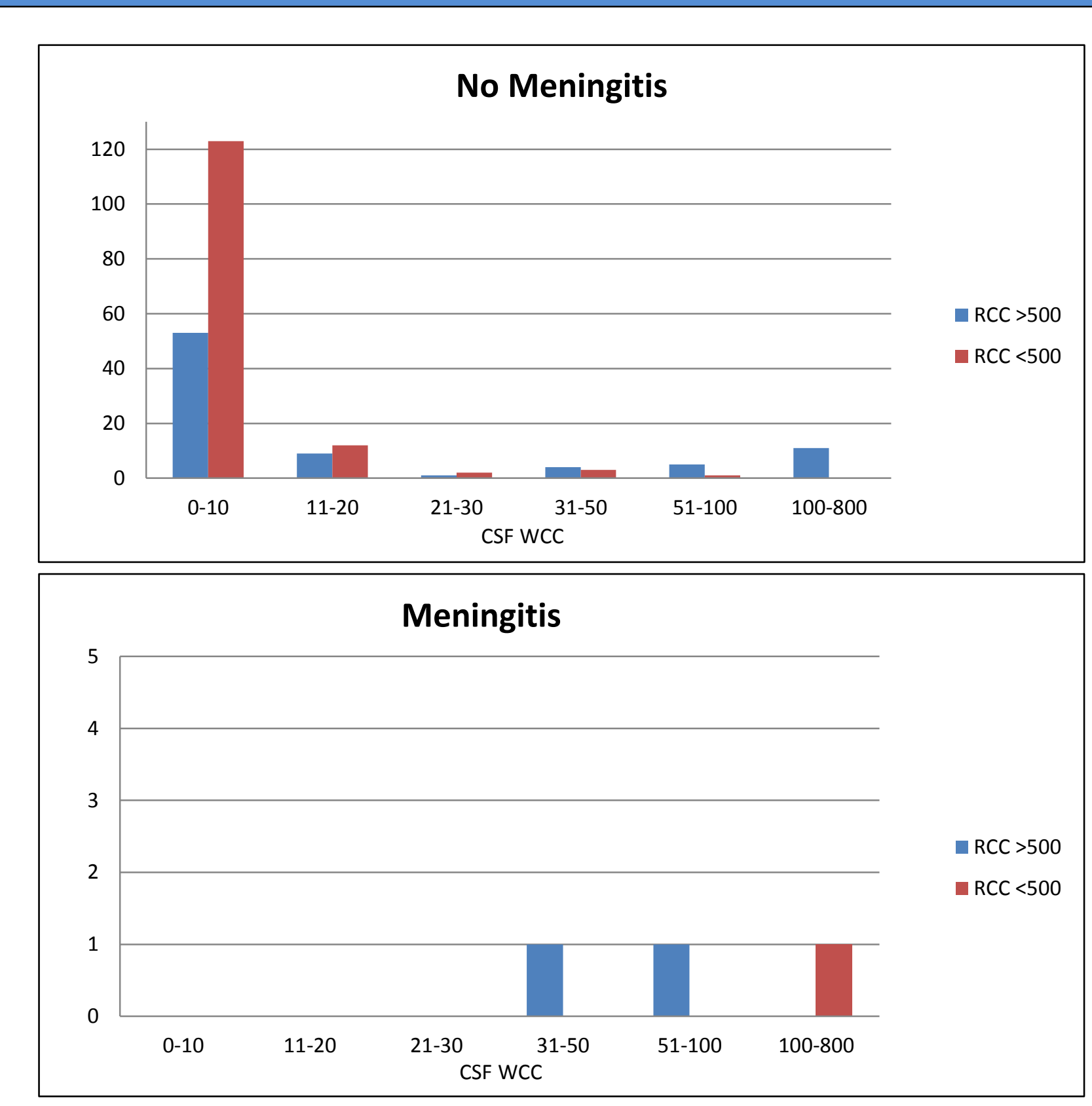

There was 1 positive GBS meningitis from 176 term neonates. The patient showed signs of severe sepsis with neurological symptoms.

In preterm babies 2 were treated for meningitis with CSF WCC of $>35 \times 10^{\wedge} 6 /$ I but both were traumatic taps with a significant white cell to red cell ratio.

Only $1.6 \%$ (4) babies completed a course of treatment for suspected meningitis based on CSF WCC, despite negative cultures and PCR.

$13.8 \%$ had an LP prior to antibiotics.

\section{Conclusion}

In term babies, LP need not be undertaken for initial sepsis screen for perinatal risk factors without signs of septicaemia, neurological signs or clinical deterioration.

An adjusted WCC did not aid the diagnosis of meningitis but a larger sample size would be beneficial to assess this further.

\section{References}

1. Greenberg R, Smith B, Cotton M et al. Traumatic lumbar punctures in neonates: Test performance of the cerebrospinal fluid white cell count. Pediatr Inf Dis J. 2008 December; 27 (12): 1047-1051

2. Kestenbaum L, Ebberson J, Zorc J et al. Defining cerebrospinal fluid white cell count reference values in neonates. Pediatr 2010; 125;257

3. Byington C, Kendrick J, Sheng X et al. Normative cerebrospinal fluid profiles in febrile infants. J Pediatr. 2011 January; 158(1): $33-37$ 